\title{
A plea for inclusive worldview education in all schools
}

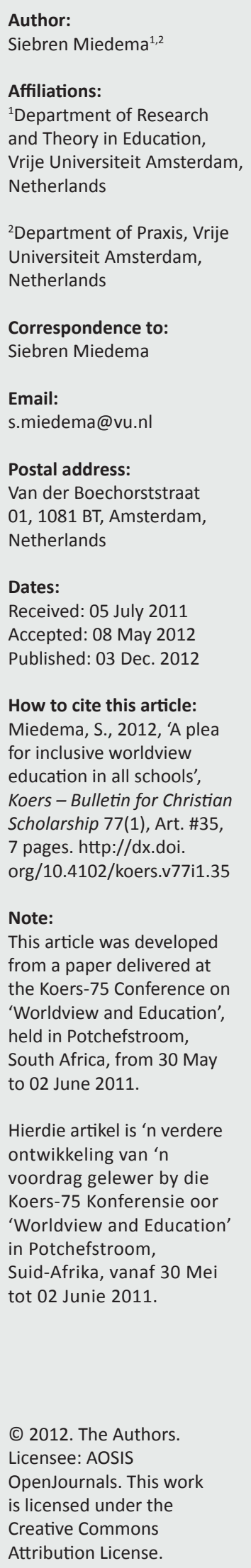

Taking personhood education ('Bildung') of students as the aim of schools, the author argues that worldview education should form an integral part of this education in all schools. It is shown that such a conceptualisation of worldview education is adequately combinable with citizenship education. In worldview-citizenship education the emphasis is first of all on students' appropriation and (continuous) development of their own worldview. A second important aim of this modus of education is that students should learn to live together in the context of the school as an embryonic society which represents different worldviews. With this two-fold aim the individual or personal and the social or communal side of the pedagogical coin are kept together. In the final part a concrete example of an inclusive practice of worldview citizenship education is described in a partnership of a Christian, a state, and an Islamic elementary school in the area of Amsterdam South-East.

'n Pleidooi vir inklusiewe lewensbeskoulike vorming in alle skole. Indien die doel van skole die persoonsvorming ('Bildung') van leerders is, behoort lewensbeskoulike vorming in alle skole ' $n$ integrale deel hiervan uit te maak, argumenteer die outeur. Daar word aangetoon dat so 'n beskouing van lewensbeskoulike persoonsvorming uitstekend gekombineer kan word met burgerskapsvorming. In lewensbeskoulike burgerskapsvorming word die klem allereers gelê op leerders se toe-eiening en (verdere) ontwikkeling van 'n eie lewensbeskouing. ' $n$ Tweede doelstelling vir sodanige ontwikkeling is dat die leerders behoort te leer om in die skool saam te leef met ander persone wie se lewensbeskouings verskil van hulle eie lewensbeskouing. Op hierdie wyse word die individuele perspektief en die sosiale of gemeenskapsperspektief beskou as twee kante van dieselfde munt. Ten slotte word ' $n$ praktiese voorbeeld waarin die doel van lewensbeskoulike burgerskapsvorming konkreet uitgebeeld word, gebied deur te wys op die samewerking van ' $n$ christelike, openbare en islamitiese primêre skool in Suidoos-Amsterdam.

\section{Introduction}

Taking my own country as an example, we noticed that, at the start of the 21st century, the Netherlands has transformed from a secular and de-pillarised society into a plural, postmodern society. That society is not only multilingual, multicultural and multiethnic, but it is also very prominently a society that has changed in religious appearance and has become multi-religious. This last change is one of the consequences of the stream of immigration that has started as early as the sixties of the 20th century. The presence of Islam is one of the most striking and visible examples of this development. Especially after ' $9 / 11^{\prime}$, most of the debates on religion have been triggered by this particular presence, and unfortunately enough, mostly in a negative way.

Another remarkable fact is that religion has been more persistent in society and in the public domain than was expected on the basis of the developments in the sixties and seventies of the previous century. Religion and reason were, for a long time, diametrically opposed to each other, with secularisation characterised as a victory of reason over religion. This oppositional stance has been undermined in the postmodern era. However, from this perspective, we should also take seriously the third form of secularity that Charles Taylor (2007) distinguishes when pointing to:

a move from a society where belief in God is unchallenged and indeed, unproblematic, to one in which it is understood to be one option among others, and frequently not the easiest to embrace. (...) Secularity in this sense is a matter of the whole context of understanding (i.e. matters explicitly formulated by almost everyone, such as the plurality of options, and some which form the implicit, largely unfocussed background of this experience and this search) in which our moral, spiritual or religious experience and search takes place. (p. 3)

In most of the societal structures in which we now live, we notice that both religions and worldviews are characterised by a strong post-traditional tendency towards individualisation, 
and religions and worldviews which still have all the identity marks of traditionality - such as a strong connectedness to a community - are all at the same time part of plural and multi-religious societies. Taking this make-up of societal structures as a starting point, pedagogically speaking, the interesting question is whether there is a place for worldview education in schools. To be even more precise, we can ask whether there is a place for worldview education in all denominational and all state schools. If the answer is positive, the next issues to be addressed have to do, respectively, with the aim of worldview education, how this mode of education could be part of a general conception of the aim of education and whether a fruitful relationship with civic or citizenship education is possible. To follow this train of thought, the first focal point in this contribution is the allembracing pedagogical aim of personhood education. The second focal point deals with worldview education and its relationship to the aim of personhood education. The third focal point deals with the question of whether a fruitful link is possible between this view on worldview education and (a particular conception of) citizenship education. Finally, I will focus on an example of good cooperative practice in the area of Amsterdam South-East, embodying a promising joint practice in which three elementary schools are cooperating: a state school, a Christian school and an Islamic school.

The aim of the example is to show that the particular identity of the schools - be it Christian, humanist or Muslim - can be preserved and in the very process of cooperation even be strengthened due to growing awareness of communalities and differences (including the different truth claims regarding particular worldviews) within schools as well as among schools. Christian schools might interpret such cooperation as being part of their ecumenical task. Such a task could mean presenting and representing the Bible and the Christian tradition in the midst of such a partnership to staff, students and parents from different religion(s) and/or worldview(s). That means putting the light of the Gospel on a stand so that the light can be perceived by all who are in the three cooperating schools (see Mt 5:14-15).

A presupposition for entering into such a process of cooperation with different denominational and state schools for both staff and parents is openness and respect, in principle, for the worldview of others. The same of course holds for the students. A real dialogue and encounter between representatives of different worldviews is only possible on the basis of strong and acknowledgeable worldview positions on the part of the participating schools. Pedagogically speaking, however, the focus will be both on organised worldviews, in terms of bringing in parts of the particular worldview traditions, and the personal worldviews of the teachers. These will form the 'educative stuff' for the students, allowing them to get acquainted with their own worldview tradition and the other worldview traditions at institutional as well as personal level. It will also allow them to be stimulated in the process of their own worldview formation on the basis of worldview education. Students also learn to live together with students adhering to different worldviews within the polis of the school.

\section{The aim of personhood education}

It is my pedagogical contention that personhood education for students should be the pedagogical aim of schools. Schools should assist students in the double process of socialisation and individuation, of becoming competent members of communities of practice. The presentation and representation of information, norms and values must always be seen in the light of how it can be transformed by students into elements of their own participation, in the process of the formation of their own personhood. This transformation is an active and dynamic process on the part of the student in which the subject matter, being the starting point, becomes the personal property of the student. The transformation is an activity authored by the students and necessary for them in order to acquire their own personhood. In this respect, it is a problem rather than an asset that schools have developed into practices in their own right, separated from the social practices into which they are supposed to introduce students because learning to participate is best done by participating.

My transformative view rests on a conceptualisation of how human beings act in the world. The basic image is that of humans as signifiers. Humans in most cases do not make explicit decisions for action based on objective knowledge of the alternatives. Instead, by being bodily in the world and transacting with it, they form images and meanings on which they act. There is thus a continuous interplay between action, signification and reflection. Meanings are never 'objective' but are always the result of the momentary and creative relationship between the human being and its environment, a relationship that may be characterised most adequately as 'a moving whole of transacting parts' (Dewey 1980:291). According to Dewey (1980), not all transactional relationships:

... ask to be known, and it certainly does not ask leave from thought to exist. But some existences as they are experienced do ask thought to direct them in their course so that they may be ordered and fair and be such as to commend themselves to admiration, approval and appreciation. Knowledge affords the sole means by which this redirection can be effected. (p. 296)

Knowledge is therefore not aimed purely at the continuation of action as such but at the problematical in the broadest sense of the word. Knowledge has a function for the other domains of experience (e.g. religious, moral and aesthetic). From this perspective, knowledge is 'a mode of experiencing things which facilitates control of objects for purposes of non-cognitive experiences' (Dewey 1980:98). Defining education in school in terms of participation and transformation implies that learning is seen neither as exclusively cognitive nor as an individualistic act. On the contrary, all domains of human potentiality and ability (be it cognitive, creative, moral, religious, expressive, etc.), that is, the development of the whole person, should be taken into account by the schools (see also Wardekker \& Miedema 2001).

No human being, however, ever finds herself or himself in a position in which they can signify at will and is then able 
to coordinate the created meanings with other humans at a later time. Humans are born into a culture, which means that the whole world already has a meaning. New-born humans have to acquire these meanings in order to be able to participate. Mostly, this acquisition process is, at least initially, not made explicit (in fact, the ability to 'learn' meanings in an explicit way, as in schools, has to be learned in itself); learning to participate develops by participating in socio-cultural practices. Although no two human beings construct exactly the same life-world, enough of it is shared to make communication and coordination of actions within practices possible. In fact, cultural practices may be interpreted as culturally pre-defined meaning systems that enable coordinated activities. Such meaning systems encompass interpretations of the world (including other human beings) and abilities for interacting with it in order to obtain intended results, values and norms. They are shared by the group of people that engage in the practice and thus form its associated community of practice. Thus, growing up may be described as acquiring the abilities to participate in practices or as becoming a competent member of several communities of practice.

The process of socialisation, however, includes a process of individuation, the process of personhood education, for its necessary reverse side: One cannot become a fully competent member of a community of practice if one does not contribute at an individual level. This process of individuation rests on the fact that cultural meanings have to be appropriated, transformed into one's own personality. In this process, personal elements like genetic make-up, emotions and unique experiences gained in past and present circumstances play a significant role, so that no two persons grow up to have exactly the same personality. It is precisely these interpersonal differences that make for changes in cultural practices. Some of these changes simply occur because of the different views participants bring to the practice; at other times, changes are intended. Ultimately, no practice can stay 'alive' without change; and being able to contribute to changes that are perceived as necessary is a structural element of the competence of participants. This implies that participation is never merely technical, manipulative or instrumental but always has a normative side because choices have to be made concerning the direction in which a given practice should develop (see Mead 1934:200ff.). Just like other meanings, the foundation upon which this normative side rests, like goals, ideals and values, comes into its own within the context of acting.

\section{Personhood education and worldview education}

'Worldview' is defined here as 'a more or less coherent and consistent whole of convictions and attitudes in respect with human life' (Dekker \& Stoffels 2001:33). It regards a more or less systematic meaning-giving or orientation in life. A distinction can be drawn between a more limited and specified sub-classification of institutional worldview traditions that deal with a God concept (e.g. Christianity and Islam), and these are thus religions or 'worldviews in the narrow sense', and others that do without a God concept (for instance humanism, atheism,), which are worldview traditions in the broad sense of the term. In relation to a worldview of a person, that is, a personal worldview, different perspectives can be at stake: a perspective on life and death, on sense or meaningfulness and nonsense, on good and evil, on suffering and on the ultimate aim of life.

The personal narrative of meaning-giving and making is characterised by:

1. a certain sense of symbolic content

2. commitment to or involvement in the person's own life

3. the selection and use of sources of meaning-giving

4. the cultivation of profound meaning-giving and existential experiences

5. and a certain spin-off in other areas of the life of the person. (Hijmans 1997:33)

In line with this, worldview education can be conceptualised as that part of personhood education of children and youngsters that focuses on the more or less systematic intentional as well as non-intentional meaning-making processes, relationships and practices. Here different aspects come into play, be it cognitive, affective-emotional, volitional or aspects dealing with action (see Miedema 2006a). All personhood education in schools is inherently worldview-laden because it has to do with meaning-presenting, meaning-giving, meaningmaking, meaning-taking and meaning-in-action.

Fostering worldview education can, from a pedagogical perspective, be considered as an integral part of personhood education and can form a substantial and integral part of the curriculum of every school. Worldview education should not be conceptualised exclusively in knowledge-based or cognitive terms. In that case, schools organise standalone activities which only provide so-called neutral or objective information about a worldview or about different worldviews, for example in a teaching and learning-about approach, or a religious studies approach.

In my view, the 'learning-about approach' does not provide optimal conditions for active and dynamic personhood education as was outlined earlier in the article (see Wardekker \& Miedema 2001). Besides, in worldview education, the acquisition of worldview experiences and worldview attitudes should not be separated from the wider processes of obtaining other experiences and attitudes. Any artificial distinction between the domain of worldviews and other domains of experience should be precluded (see Miedema 1995). The explicit presentation and representation of a rich and plural array of worldview 'subject matter' in the form of frames of reference, models, practices, rituals and narratives is an essential prerequisite for making individuation possible on the basis of socialisation processes. These presentations and representations are not intended simply to be transmitted by the teachers and internalised by the students in their presented or represented form, but they can be offered to the students as potentially transformative material. Such interaction between the presented material and the students is characterised by a non-dogmatic, non-compelling 'openness' 
which offers students multiple possibilities for the formation of their own personhood. Contrary to the notion of the school as an institution for the linear transmission of knowledge, skills, beliefs or worldviews, schools should function as communities of diverse practices and as communities of learners. In such schools, the students can learn to see each other as citizens of the embryonic society which the school community is (see Dewey 1972). The students of this embryonic society can learn that they are responsible for one another and must pursue their common goals through dialogue and cooperation (see Strike 2000:143).

Personhood formation through worldview education can be supported by the encouragement of a critical-evaluative attitude on the part of the students. Unquestioning acceptance or non-reflective, full identification with the views of the teacher is, to put it euphemistically, not the most appropriate practice for the development of successful personhood formation on the basis of personhood education. Rather, the focus should be upon the growth of the potential for an active and critical reconstruction of different and differing perspectives, be they ideals, norms, values, knowledge, narratives or beliefs. Such practices and processes in school will enhance the capacity of the students to integrate these perspectives into their own personality, promote the ongoing organisation and re-organisation of their perspectives and form resources for the reconstruction of the self, for selftranscendence (see Joas 2004).

\section{Worldview education and citizenship education}

Citizenship education and development for citizenship have been and still are seen globally as an important issue in the political and public debate in the first decades of the 21st century; this is also the case in the Netherlands (see Miedema \& Bertram-Troost 2008). In 2005, the Dutch Minister of Education proposed a change in the Law on Primary and Secondary Education in terms of the obligation for state schools as well as denominational schools to stimulate active citizenship and social cohesion for all students aged between 4 and 16. On 01 February 2006, this change became manifest in the law Stimulating Active Citizenship and Social Integration. A flanking brochure, to this law, bearing the title $A$ Basis for Citizenship (Bron 2006), was published by the Dutch National Institute for Curriculum Development. It is quite remarkable that in this brochure for the very first time, the particular profile and identity of the schools are also taken into account. It also raises the question of how citizenship education, worldview education and the identity of the school can be adequately related to each other, and schools are invited to deal with this. The following core concepts are mentioned in the brochure, aiming at the relationship of citizenship and worldview education: the recognition of different views, tolerance and openness for encounters with persons holding different views and opinions.

We may conclude that, from a Dutch governmental perspective, fruitful possibilities can now be distinguished to further link citizenship education and worldview education. From a historical point of view, this is remarkable to say the least because the separation of state and church since the 19th century resulted in the abstentionist situation in which the state did not deal with religious or worldview matters whatsoever (see De Ruyter \& Miedema 2000; Miedema \& Biesta 2003). It is my contention, however, that, in addition to the possibilities available, there is also the need to link worldview education and citizenship education in the secular age for the purpose of adequate worldview formation. One option here is to strengthen the view that every student's personal worldview should flourish in every school. A full concept of 'citizenship education' may imply that worldview education is part and parcel of citizenship education and should form a structural and necessary element of all citizenship education in all schools. Worldview formation is then interpreted as an integral part of the concept of personhood formation and stimulated by worldview education.

Such a view is fully compatible with inter-worldview education too when the aim is no longer educating into a worldview but rather combining educating about worldviews with educating from worldviews. The aim is then to enable students to develop their own point of view in matters of worldview in the context of plurality via encounter and dialogue. My argument here is that the education of 'worldview citizens' is based on the formation of students through processes that require them to negotiate with the perspectives of 'others' and to integrate such perspectives into their own actions and reflections in order to make sense of this personally. Educating for worldview citizenship is not just an unrealistic dream but is rather a pedagogical, theological, societal and global necessity as I will show later in the article.

So, there are fruitful possibilities to now further link worldview education and citizenship education. Terrence McLaughlin's notion of a maximalist interpretation of education for citizenship may be helpful here. He points to the necessity of a full educational program in which the development of a broad critical understanding and a much more extensive range of dispositions and virtues are seen as crucial in the light of a general liberal and political education (see McLaughlin 1992). His view on education for citizenship offers the possibility to include worldview education as part of such an educational program, making it even more comprehensive by combining democratic education for citizenship and religious education in schools. It is my contention that this combination could appropriately be coined as 'worldview citizenship education'. This is fully reconcilable with what I have earlier stated as the aim of education in schools, that is, that every student in every school should be able to develop her or his personhood. Worldview education is then to be interpreted as an integral part of an all-embracing concept of personhood education. An all-embracing concept of citizenship education should imply that worldview education is an inclusive part of citizenship education. It should form a structural and essential element 
of all citizenship education in all Schools - thus including state schools as well as denominational schools - based on a transformative pedagogy stressing the actorship and authorship of the students. The aim is the steady growth of students' self-responsible self-determination regarding worldview(s).

It is widely recognised that, in liberal-democratic societies, citizenship education is the responsibility of each country's government. However, if governments should take their responsibility for an inclusive concept of education for citizenship seriously, this could mean that, without any preference per se on the part of the government for a particular worldview or religion, each government could take the political-pedagogical responsibility to stimulate the policy and practice in schools for fostering worldview education as part of an integral conception of citizenship education (see Doedens \& Weisse 1997). States can therefore provide support by encouraging democratic citizenship and worldview education at the same time.

Following the train of thought of the philosopher and pedagogue John Dewey (see Dewey 1972; 1916), it is, in my opinion, desirable, pedagogically speaking and from a societal perspective, that, already in the embryonic society of the school, students gradually and in respect to their development experience or are confronted with other students' worldviews, backgrounds, ideas, experiences and practices and, in this way, become acquainted with it. In this way, they learn to deal with cultural, ethnic and worldview diversity and difference. Seeing the impact of a worldview on political, cultural and economic areas, they can also benefit from such experiences and insights when they encounter 'others' with a different worldview in society at large. So, from a societal as well as a pedagogical point of view, all schools should be obliged to foster a worldview dimension to citizenship and thereby bring about mutual respect and understanding and stimulate the development of the personal worldview formation of students in school (see Miedema 2006b).

\section{An example of inclusive practice}

Personhood education, and thus personhood formation, have their own rights sui generis and should not be used in an instrumental way for societal goals. The students may of course profit from the experiences, knowledge and insights gained by participating in school practices when they later take part in and contribute to society at large and its cultural practices. In this section, I shall describe a concrete example of a cooperative school practice in Amsterdam South-East. It is also an example of learning to live together with different worldviews.

In the 'Bijlmer' district in the south-east of the city of Amsterdam, three primary schools belonging to different denominations - that is a state school, an Islamic school and an open Christian school - practice what they preach and preach what they practice: living together in difference.
In these three schools, teachers, students and parents represent different nationalities and a variety of worldview commitments. The pedagogical approach used here has been coined the 'Bijlmer Conversations', and emphasise the need to draw each other into the conversation continuously. Although the teachers play a central role in the 'Bijlmer Conversations', the focus is on the needs of the student who is raised and who will also live in a multicultural and multi-religious society. As such, this model is close to the model the Juliana van Stolberg school - the only state-recognised interreligious school in the Netherlands until July 2003 - had used, focussing also on the educational needs of the student (Ter Avest \& Miedema 2012).

The three elementary schools in the Bijlmer have made a decision for close cooperation because the problematic situation of most of the students in this poorer area of Amsterdam, where more than seventy different nationalities and over twenty denominational backgrounds are represented, is perceived by the principals of these three schools as a shared problem. This background forms the main focus of their pedagogical task. In the team meetings, the abovementioned 'Bijlmer Conversations', the teams of the three schools (individually and jointly) develop their own way of responding to the diversity of their student population and the complexity of the acculturation and adjustment of the students. The voice of the teacher, the variety of sources of inspiration, the voice of the student and the need of the students to be equipped to live alongside one another in the multicultural and multi-religious society are combined in the pedagogical approach of 'learning in difference' of the 'Bijlmer Conversations'.

The different pedagogical strategies of each of the three teams are rooted in the personal, that is, the religious or secular, worldview of the members of the team. Religion is seen as something you have to know about and you can learn from, provided that there is a certain sensitivity towards, and recognition of, situations and experiences of awe, of practices that render speechless. Diversity in religious and secular worldviews is regarded as a given, as a societal fact and as a challenge rather than a problem.

Creating social cohesion as a network of teachers and parents from different cultural and religious backgrounds is seen as a challenge. For the creation of such networks, each of the partners is of equal importance, or to put it differently: The schools are not able to develop their own identity without the contrasting or confronting encounters with the other schools. The slogan of the schools is: The Plural of Togetherness is Future. The schools' characteristic approach to difference is cemented in classroom activities stimulating the development of social competencies and is based on the respectful encounter of students of different religious backgrounds. Respect and tolerance are a main focus of citizenship education.

The three teams have agreed upon teaching and learning according to the pedagogical strategy of Peaceful Education, 
a pedagogical strategy of stimulating the development of social competencies for learning to live alongside and with each other. According to the principals of these schools, Peaceful Education contributes to good citizenship. They aim to elaborate on this approach, which should result in a so-called 'pedagogical constitution'. This pedagogical constitution is meant not only for the school community but also for the schools' environment in which the children live: the neighbourhood, including sports clubs and other organised leisure activities. The objective is thus to establish a basis for post-pillarised education in the Netherlands.

Central to the 'Bijlmer Approach' is the teacher's pedagogical approach of 'guided openness'. This pedagogical approach, rooted in the interreligious model developed in the last decade of the 20th century and further developed and articulated in the first decade of the 21st century, is characterised by four aspects represented in the concepts of knowledge (of religious and secular traditions) and literacy, recognition (of similarities and differences), further exploration (of similarities and differences) and knowledge construction emerging from the dialogical encounter with the other:

- The first aspect, of knowledge and literacy, emphasises knowing how to do things, how to participate in a context of religiosity: the kind of knowledge a student constructs by imitation and participation. At schools, this tacit knowledge, obtained by observation and imitative actions, is made explicit.

- The second aspect, of recognition, points to the student sharing her or his impressions and knowledge with other students he or she meets in his or her and in the other two schools. She or he recognises what the impressions and knowledge have in common with others as well as the similarities in the rituals at her or his friends' house. The student also notices what is different - a difference that makes the child aware of its own uniqueness and the other's difference. In his or her own the child feels at home in the world; in school the child becomes a literate in the world.

- The third aspect, of exploration, points to the possibility of a change in perspective: The child leaves her or his own world to enter into the world of the other and sees the world through the eyes of the other. In entering the world of 'the other', classmates provide knowledge about the other's worldview and its meaning in the life of a member of the peer group. In addition to acquiring knowledge, the student is guided into the comparison and assessment of contrasting or even conflicting ways of interpreting religious or worldview traditions and different ways of giving meaning to life. This change in perspective is not at all easy. The child needs caring guidance to let go of her or his own point of view and to strengthen the will to meet 'the other'. In school, it is the teacher's approach of guided openness that encourages the student to explore and question the other's point of view as well as her or his own worldview.

- The teacher, in her pedagogical strategy of guided openness, is a role model for the student and holds out the perspective of the fourth characteristic aspect of the Bijlmer Approach: the real encounter with the other, an encounter that makes a difference to the student. In this encounter, new perspectives change the students' position towards their own tradition as well as the position towards the traditions of others. Prejudices are cut down and mutual understanding is established, being a precondition for living together as citizens in a plural society. The pedagogical strategy so characteristic for the Bijlmer Approach, and elsewhere coined as 'provocative pedagogy' (Ter Avest \& Bertram-Troost 2009), is an approach that makes a difference for students and that makes students different. The participants in this project, the principals of the three schools as well as the teachers, are convinced of the necessity of their pedagogical strategy, pointing to the shared theme of the need for social cohesion in a future world - a world that distinguishes itself in many respects from today's world. Principals, teachers and parents support this model, not because they want the students to solve all the problems in society, as they all know that school cannot fully compensate for society, but because they want the school to act as an interspace for the students. This interspace constitutes a space between socialisation at home and later taking part in society at large. The adults committed to this model reflect upon the aspects of today's society that are worthwhile to pass on to the next generation in order to stimulate the students' development as future citizens of a different world (Berding 2009).

\section{Conclusion}

In pleading for inclusive worldview education in all schools, I have dealt with a couple of issues. My first focal point was the aim of personhood education. The second point focussed on the question of whether worldview education can find a place in personhood education of students. The third main point dealt with the question of whether a fruitful link is possible of such a view on worldview education with a particular conception of citizenship education. Finally, I focussed on an example of cooperative practice in Amsterdam SouthEast as an example of a promising partnership in which three elementary schools are cooperating: a state school, a Christian school and an Islamic school. It is my contention that such forms of cooperation could be and possibly will be realised at a local level in many other countries too, with separate school management and budgetary responsibilities, or in the form of a complete partnership. The prerequisite for such practices of inter-worldview education in the school setting is that both the participating denominational schools as well as the state schools interpret worldview education as an integral part of an all-embracing concept of personhood formation and combine this with a transformative pedagogy, stressing the actorship and authorship of the students regarding their worldview formation.

\section{Acknowledgements Competing interests}

I declare that I have no financial or personal relationships which may have inappropriately influenced me in writing this article. 


\section{References}

Berding, J., 2009, 'Het onmeetbare handelen - Hannah Arendt over de fragiliteit van de opvoeding' [The immeasurable act - Hannah Arendt on the fragility of the education], Pedagogiek 29, 140-153.

Bron, J., 2006, Een basis voor burgerschap: Een inhoudelijke verkenning voor het funderend onderwijs [A basis for citizenship: An exploration for primary and secondary schools], SLO/Dutch National Institute for Curriculum Development Enschede.

Dekker, G. \& Stoffels, H.C., 2001, Godsdienst en samenleving - Een introductie in de godsdienstsociologie, Kok, Kampen.

De Ruyter, D.J. \& Miedema, S., 2000, 'Denominational schools in the Netherlands', in M. Leicester, C. Modgil \& S. Modgil (eds.), Education, culture and values, Vol. v., Spiritual and Religious Education, pp. 133-141, Falmer Press, London.

Dewey, J., 1916, Democracy and education: An introduction to the philosophy of education, The Free Press, New York.

Dewey, J., 1972, 'My pedagogic creed', in J.A. Boydston (ed.), John Dewey - The Early Works, Vol. 5, pp. 84-95, Southern Illinois University Press, Carbondale and Edwardsville.

Dewey, J., 1980, The quest for certainty, Perigee Books, New York.

Doedens, F. \& Weisse, W. (eds.), 1997, Religionsunterricht für alle - Hamburger Perspektiven zur Religionsdidaktik, Waxmann, Münster.

Hijmans, E., 1997, 'Levensbeschouwing als alledaags verschijnsel', in A. Smaling \& Hijmans, E., (reds.), Kwalitatief onderzoek en levensbeschouwing, pp. 33-51, Boom, Amsterdam.

Joas, H., 2004, Braucht der Mensch Religion? Ueber Erfahrungen der Selbsttranszendenz, Herder, Freiburg.

McLaughlin, T.H., 1992, 'Citizenship, diversity and education: A philosophical perspective', Journal of Moral Education 21, 235-250.
Mead, G.H., 1934, Mind, self, and society from the standpoint of a social behaviorist, University of Chicago Press, Chicago.

Miedema, S., 1995, 'The beyond in the midst: The relevance of Dewey's philosophy of religion for education', in J. Garrison (ed.), The new scholarship on Dewey, pp. 61-73, Kluwer Academic Publishers, Dordrecht.

Miedema, S. \& Biesta, G.J.J., 2003, 'Instruction or educating for life? On the aims of religiously-affiliated schools and others', International Journal of Education and Religion 4, 81-96.

Miedema, S., 2006a, 'Public, social, and individual perspectives on religious education: Voices from the past and the present', Studies in Philosophy and Education 25, 111-127.

Miedema, S., 2006b, 'Educating for religious citizenship. Religious education as identity formation', in M. De Souza, K. Engebretson, G. Durka, R. Jackson \& A McGrady (eds.), International handbook of the religious, spiritual and moral dimensions of education, Vol. I \& II, pp. 965-974, Springer, Dordrecht.

Miedema, S. \& Bertram-Troost, G.D., 2008, 'Democratic citizenship and religious education: Challenges and perspectives for schools in the Netherlands', British Journal of Religious Education 30, 123-132.

Strike, K.A., 2000, 'Liberalism, communitarism and the space between: In praise of kindness', Journal of Moral Education 29, 133-147.

Taylor, C., 2007, A secular age, The Belknap Press of Harvard University Press, Cambridge.

Ter Avest, I. \& Bertram-Troost, G.D., 2009, 'Provocatieve pedagogiek en didactische strategieën', in K.H. Ter Avest \& G.D. Bertram-Troost (eds.), Geloven in samen leven, pp. 120-135, Gopher/Science Guide, Amsterdam.

Ter Avest, I. \& Miedema, S., 2012, 'Religious citizenship education. Towards a new post-pillarized approach for all schools in the Netherlands', in H. Vroom, T. Sunier, P. Versteeg \& S. Huisman (eds.), pp. Democracy, culture, and religion, Rodopi, Amsterdam.

Wardekker, W.L. \& Miedema, S., 2001, 'Identity, cultural change and religious education, British Journal of Religious Education 23, 76-87. 